Journal Club

Editor's Note: These short, critical reviews of recent papers in the Journal, written exclusively by graduate students or postdoctoral fellows, are intended to summarize the important findings of the paper and provide additional insight and commentary. For more information on the format and purpose of the Journal Club, please see http://www.jneurosci.org/misc/ifa_features.shtml.

\title{
Dissecting the Role of P/Q-Type Calcium Channels in Corticothalamic Circuit Dysfunction and Absence Epilepsy
}

\author{
Rebecca Shi, Gabrielle M. Schroeder, and Akua F. Nimarko \\ Stanford Neurosciences Graduate Program, Stanford University, Stanford, California 94305 \\ Review of Bomben et al.
}

The corticothalamic network is responsible for producing many forms of neural oscillations, such as sleep spindles and the slow-wave $(<1 \mathrm{~Hz})$ rhythm (Crunelli et al., 2006). The rhythm-generating properties of this circuit depend on reciprocal excitatory connectivity between the cortex and thalamus, as well as intrathalamic circuitry and the intrinsic properties of thalamic neurons (Huguenard and McCormick, 2007; Fig. 1A). Thalamic relay neurons project both to the cortex and to the reticular thalamic nucleus, which provides inhibitory feedback to the thalamic relay cells. Due to their high expression of T-type calcium channels, which are deinactivated at hyperpolarized membrane potentials, both thalamic relay and reticular neurons fire rebound bursts following release from sustained hyperpolarization; this can establish an oscillatory cycle between bursting thalamic relay cells and inhibitory reticular neurons (Huguenard and McCormick, 2007).

Oscillatory activity in thalamocortical circuits has important physiological functions, but dysfunction of the circuit can produce pathological oscillations in the form of spike-wave discharges (SWDs; Huguenard and McCormick, 2007), the

Received March 7, 2016; revised April 6, 2016; accepted April 11, 2016. We thank Aaron Gitler and Helen Yang for their thoughtful comments on this journal club.

The authors declare no competing financial interests.

Correspondence should be addressed to Rebecca Shi, 935 0ak Lane, Apartment A, Menlo Park, CA 94025. E-mail: beckyshi@stanford.edu. DOI:10.1523/JNEUROSCI.0753-16.2016

Copyright $\odot 2016$ the authors $\quad 0270-6474 / 16 / 365677-03 \$ 15.00 / 0$ characteristic electrographic signature of absence epilepsy (Commission on Classification and Terminology of the International League Against Epilepsy, 1989). In absence seizures, stereotyped 3-4.5 Hz (5-8 Hz in rodent models) SWDs are broadly generalized throughout the cortex, indicating abnormal global synchronous activity (Tenney and Glauser, 2013; Maheshwari and Noebels, 2014).

The majority of genetic mutations associated with SWDs affect ion channel function (Maheshwari and Noebels, 2014), indicating that alterations in these channels likely contribute to the production of pathological thalamocortical activity. Of particular interest are mutations in $\mathrm{P} / \mathrm{Q}$-type voltage-gated calcium channels, which mediate neurotransmitter release (Neher and Sakaba, 2008). In mice, complete or partial loss of function of these channels produces a spike-wave epilepsy phenotype, likely due to an accompanying increase in thalamic T-type calcium currents that renders the thalamus hyperexcitable (for review, see Zamponi et al., 2010). Because global knock-outs affect multiple nodes of the corticothalamic network, as well as remote regions, previous genetic models have been unable to determine the mechanism underlying this upregulation of thalamic T-type currents. Past experimental and theoretical work indicates that neurons may homeostatically regulate their intrinsic ionic conductances in an attempt to maintain network activity and function (Golowasch et al., 1999; O'Leary et al., 2014). Thus, in global knock-outs, it is unclear whether compensatory changes in thalamic T-type currents are driven by the loss of $\mathrm{P} / \mathrm{Q}$ currents in thalamic neurons themselves, or by aberrant synaptic transmission from cortical neurons lacking P/Q currents.

In a study published in The Journal of Neuroscience, Bomben et al. (2016) investigated the effects of altered P/Q channels on corticothalamic dynamics using Cacna $1 a^{\mathrm{Ntsr}(-1-)}$ mice. These mutant mice have a selective deletion of the $\mathrm{P} / \mathrm{Q}$ channel $\alpha$ subunit gene Cacnala in cortical layer VI pyramidal neurons, which project to thalamic relay and reticular cells (Bomben et al., 2016, their Fig. 1). Because this mutation is a cortical cellspecific deletion, Bomben et al. (2016) avoid the confounds of a global knock-out and can determine whether loss of $\mathrm{P} / \mathrm{Q}$ currents in cortical neurons is sufficient to alter T-type currents in thalamic neurons.

First, to investigate the impact of this mutation on the generation of spike-wave epilepsy, Bomben et al. (2016) performed electroencephalogram experiments on wild-type and mutant Cacnala ${ }^{\mathrm{Ntsr}(-1-)}$ mice. Cacnala $a^{\mathrm{Ntsr}(-1-)}$ mice displayed frequent SWDs (Bomben et al., 2016, their Fig. 5). To further characterize this phenotype, the authors examined whether Cacnala $a^{\mathrm{Ntsr}(-1-)}$ mice were sensitive to ethosuximide, a T-type calcium channel blocker (Chen et al., 2014). As in tottering mice, which have a global partial loss of P/Q currents (Fletcher et al., 1996), and other spike-wave epilepsy mouse models (Chen et al., 2014), ethosuxi- 
mide rapidly suppressed SWDs in Cacnala $a^{\mathrm{Ntsr}(-1-)}$ mice. These results suggest that mice lacking P/Q-type calcium channels in layer VI cortical neurons still exhibit T-type calcium currents sensitive to ethosuximide, and a reduction of T-type currents is sufficient to suppress spike-wave epilepsy. Future studies will be needed to determine whether the loss of T-type currents in thalamic relay cells rescues the epileptic phenotype in Cacnala ${ }^{\mathrm{Ntsr}(-/-)}$ mice, as is the case in other spike-wave epilepsy models including tottering (Song et al., 2004).

Previous studies (Jun et al., 1999; Saito et al., 2009; Noebels, 2012) have shown that genomic mutations of Cacnala cause partial or complete ataxia, but whether this effect involved corticothalamic projections was unknown. To assess whether the knock-out of P/Q-type calcium channels in layer VI cortical neurons produces abnormal motor control, Bomben et al. (2016) assayed balance, agility, and gait in wild-type and Cacnala $a^{\mathrm{Ntsr}(-l-)}$ mice. Interestingly, only a small, yet significant, difference in motor coordination deficit was observed in Cacnala $a^{\mathrm{Ntsr}(-1-)}$ using the ledge test (Bomben et al., 2016, their Fig. 9). The authors could not visually detect impaired motor behaviors in Cacnala $a^{\mathrm{Ntsr}(-1-)}$ mice, indicating that the ataxia seen in other mouse models is produced by circuits outside the corticothalamic pathway, such as those involving the cerebellum (Mark et al., 2011).

Having examined the behavioral and epileptic phenotypes of Cacnala $\mathrm{Ntsr(-I-)}^{\mathrm{N}}$ mice, Bomben et al. (2016) next characterized changes at the corticothalamic relay synapse using whole-cell patch-clamp of thalamic relay neurons while electrically stimulating corticothalamic white-matter tracts in acute slices. Synapses lacking P/Q channels showed no difference in pairedpulse facilitation, a standard way of estimating neurotransmitter release probability (Branco and Staras, 2009). The authors then used an N-type calcium channel toxin to show that $\mathrm{N}$-type channels played a robustly increased role in mediating neurotransmitter release at synapses lacking P/Q channels (Bomben et al., 2016, their Fig. 3). Because $\mathrm{P} / \mathrm{Q}$-type and N-type calcium channels are the principal channel types responsible for neurotransmitter release (Zamponi et al., 2010; Maheshwari and Noebels, 2014), this result suggests that $\mathrm{N}$-type calcium channel activity is upregulated to compensate for a P/Q-type channel deletion.

Strikingly, the authors showed that, just as in the global P/Q channel knockdown tottering (Zhang et al., 2002), the

A

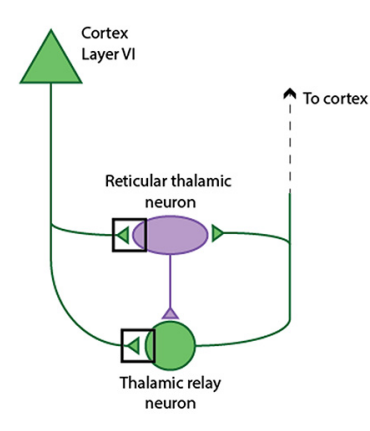

B

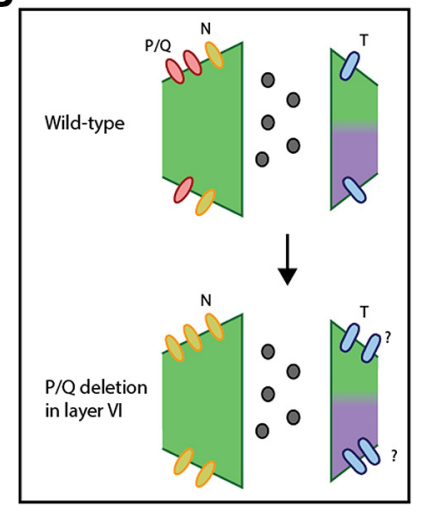

Figure 1. Schematic of the corticothalamic circuit and changes following P/Q-type calcium channel deletion in layer VI cortical neurons. $\boldsymbol{A}$, Schematic of the corticothalamic circuit. Layer VI pyramidal cells of the cortex send excitatory projections onto thalamic relay neurons and the surrounding reticular thalamic neurons. Thalamic relay neurons send excitatory projections back to the cortex (primarily layer IV) and reticular thalamic neurons. Reticular thalamic neurons inhibit thalamic relay neurons and "gate" information flow from the thalamus to the cortex (Huguenard and McCormick, 2007). Black squares are expanded in B. B, Effects of deleting P/Q-type calcium channels in layer VI neurons. Corticothalamic relay synapses show increased N-type channelmediated neurotransmitter release. Through an unknown mechanism, both postsynaptic thalamic relay neurons and reticular thalamic neurons show an increase in T-type calcium channel currents (Bomben et al., 2016).

targeted presynaptic cortical deletion in Cacna1 $a^{\text {Ntsr(-)- }}$ mice changed electrophysiological properties in postsynaptic thalamic neurons. Using whole-cell patch-clamp of thalamic relay or reticular thalamic neurons, the authors used a hyperpolarizing current pulse to activate T-type channels in these postsynaptic cells. Cacnala $a^{\mathrm{Ntsr}(-)-)}$ mice exhibited increased T-type currents in both types of thalamic cells (Bomben et al., 2016, their Figs. 5, 6; Fig. 1B). Cacnala $a^{\mathrm{Ntsr}(-1-)}$ reticular thalamic neurons also showed an increase in the number of rebound burst action potentials following the hyperpolarizing pulse.

Because these increases in T-type channel currents were not mediated by an increase in T-type channel mRNA expression (Bomben et al., 2016, their Fig. 8), the authors speculated that T-type channels may be differentially post-translationally modified in Cacnala $a^{\mathrm{Ntsr}(-1-)}$ mice. Posttranslational modifications would allow for changes in ion channel conductance, kinetics, or surface expression without changes in overall mRNA or protein levels. Previous studies indicate that posttranslational modifications can indeed modify ion channel properties; for example, phosphorylation of voltage-gated sodium channels by PKA or PKC can reduce peak sodium current in rat hippocampal neurons (Numann et al., 1991; Schulz et al., 2008), and phosphorylation of voltage-gated sodium channels by PKA in rat dorsal root ganglion neurons can increase peak sodium currents while also increasing channel activation and inacti- vation rates (Gold et al., 1998; Schulz et al., 2008). Furthermore, phosphorylation of voltage-gated potassium channels (Yang et al., 2007) and ubiquitination of AMPA receptors (Huo et al., 2015) can regulate surface expression of these ion channels. To expand on the Bomben et al. (2016) study, one could use a surface biotinylation experiment to determine whether an increase in surface expression of thalamic T-type channels is responsible for the increased T-type channel currents in Cacnala $a^{\mathrm{Ntsr}(-/-)}$ mice.

How can a presynaptic $\mathrm{P} / \mathrm{Q}$ channel deletion lead to a postsynaptic change in T-type calcium currents? Although the authors speculate that $\mathrm{P} / \mathrm{Q}$ channel deletion may cause a change in neurotransmitter release that can then mediate transsynaptic effects, the current paper does not fully test this possibility. Pairedpulse facilitation at the corticothalamic relay synapse was unchanged in knockout animals (Bomben et al., 2016, their Fig. 3), suggesting that release probability is grossly unchanged in knock-out synapses. Further work is needed to determine whether other aspects of neurotransmitter release are affected in Cacnala ${ }^{\text {Ntsr(-l-) }}$ mice. For example, one could examine whether P/Q channel deletion affects the readily releasable pool of vesicles using a high-frequency stimulus train analysis (Fioravante et al., 2011). In addition, although it is not possible to detect changes in quantal vesicle release in the current system due to the numerous remaining $\mathrm{P} / \mathrm{Q}$ channel-containing projections (Bomben et al., 2016, their Fig. 2), 
one could investigate changes in the amplitude of a quantal response using optogenetic stimulation in the presence of strontium (Lerner et al., 2015).

Beyond the scientific advances presented in this study, the authors' generation of a Cre-dependent P/Q channel deletion opens the door for generating other mice with inducible Cre-dependent $\mathrm{P} / \mathrm{Q}$ channel deletions, enabling spatial and temporal specificity of the P/Q channel knock-out. Such mice could give insight into whether changes seen in Cacna $1 a^{\mathrm{Ntsr}(-/-)}$ mice result from longterm developmental effects or short-term acute effects of $\mathrm{P} / \mathrm{Q}$ channel deletion. For instance, it is possible that the postsynaptic increase in T-type calcium currents does not result directly from a presynaptic $\mathrm{P} / \mathrm{Q}$ channel deletion, but rather from the circuit's homeostatic regulatory mechanisms. In any case, the inducible Cre system would allow further dissection of when and where $\mathrm{P} / \mathrm{Q}$ calcium channels are necessary for maintaining a normal corticothalamic microcircuit, thereby giving insight into how their dysfunction can contribute to the generation of SWD.

Thus, through a cell-type-specific knock-out, Bomben et al. (2016) have advanced our understanding of how the loss of P/Q-type calcium currents contributes to altered intrinsic properties of thalamic neurons and ultimately pathological oscillatory activity. Although the mechanism underlying altered thalamic T-type currents in Cacnala $a^{\mathrm{Ntsr(-/-)}}$ mice remains unknown, future work can continue to probe the role of both $\mathrm{P} / \mathrm{Q}$-type and T-type calcium channels in corticothalamic circuit dysfunction and absence epilepsy.

\section{References}

Bomben VC, Aiba I, Qian J, Mark MD, Herlitze S, Noebels JL (2016) Isolated P/Q calcium channel deletion in layer VI corticothalamic neurons generates absence epilepsy. J Neurosci 36:405-418. CrossRef Medline

Branco T, Staras K (2009) The probability of neurotransmitter release: variability and feedback control at single synapses. Nat Rev Neurosci 10:373-383. CrossRef Medline

Chen Y, Parker WD, Wang K (2014) The role of
T-type calcium channel genes in absence seizures. Front Neurol 5:45. CrossRef Medline

Commission on Classification and Terminology of the International League Against Epilepsy (1989) Proposal for revised classification of epilepsies and epileptic syndromes. Epilepsia 30:389-399. CrossRef Medline

Crunelli V, Cope DW, Hughes SW (2006) Thalamic T-type Ca2+ channels and NREM sleep. Cell Calcium 40:175-190. CrossRef Medline

Fioravante D, Chu Y, Myoga MH, Leitges M, Regehr WG (2011) Calcium-dependent isoforms of protein kinase $\mathrm{C}$ mediate posttetanic potentiation at the Calyx of Held. Neuron 70: 1005-1019. CrossRef Medline

Fletcher CF, Lutz CM, O'Sullivan TN, Shaughnessy JD Jr, Hawkes R, Frankel WN, Copeland NG, Jenkins NA (1996) Absence epilepsy in tottering mutant mice is associated with calcium channel defects. Cell 87:607-617. CrossRef Medline

Gold MS, Levine JD, Correa AM (1998) Modulation of TTX-R INa by PKC and PKA and their role in PGE2-induced sensitization of rat sensory neurons in vitro. J Neurosci 18:1034510355. Medline

Golowasch J, Casey M, Abbott LF, Marder E (1999) Network stability from activity-dependent regulation of neuronal conductances. Neural Comput 11:1079-1096. CrossRef Medline

Huguenard JR, McCormick DA (2007) Thalamic synchrony and dynamic regulation of global forebrain oscillations. Trends Neurosci 30:350-356. CrossRef Medline

Huo Y, Khatri N, Hou Q, Gilbert J, Wang G, Man HY (2015) The deubiquitinating enzyme USP46 regulates AMPA receptor ubiquitination and trafficking. J Neurochem 134: 1067-1080. CrossRef Medline

Jun K, Piedras-Rentería ES, Smith SM, Wheeler DB, Lee SB, Lee TG, Chin H, Adams ME, Scheller RH, Tsien RW, Shin HS (1999) Ablation of $\mathrm{P} / \mathrm{Q}$-type $\mathrm{Ca}(2+)$ channel currents, altered synaptic transmission, and progressive ataxia in mice lacking the alpha(1A)-subunit. Proc Natl Acad Sci U S A 96:15245-15250. CrossRef Medline

Lerner TN, Shilyansky C, Davidson TJ, Evans KE, Beier KT, Zalocusky KA, Crow AK, Malenka RC, Luo L, Tomer R, Deisseroth K (2015) Intact-brain analyzes reveal distinct information carried by $\mathrm{SNc}$ dopamine subcircuits. Cell 162:635-647. CrossRef Medline

Maheshwari A, Noebels JL (2014) Monogenic models of absence epilepsy: windows into the complex balance between inhibition and excitation in thalamocortical microcircuits. Prog Brain Res 213:223-252. CrossRef Medline

Mark MD, Maejima T, Kuckelsberg D, Yoo JW, Hyde RA, Shah V, Gutierrez D, Moreno RL, Kruse W,
Noebels JL, Herlitze S (2011) Delayed postnatal loss of P/Q-type calcium channels recapitulates the absence epilepsy, dyskinesia, and ataxia phenotypes of genomic Cacnala mutations. J Neurosci 31:4311-4326. CrossRef Medline

Neher E, Sakaba T (2008) Multiple roles of calcium ions in the regulation of neurotransmitter release. Neuron 59:861-872. CrossRef Medline

Noebels JL (2012) The voltage-gated calcium channel and absence epilepsy. In: Jasper's Basic Mechanisms of the Epilepsies, Ed 4 (Noebels JL, Avoli M, Rogawski M, Olsen R, Delgado-Escueta A, eds). Bethesda, MD: National Center for Biotechnology Information.

Numann R, Catterall WA, Scheuer T (1991) Functional modulation of brain sodium channels by protein kinase $\mathrm{C}$ phosphorylation. Science 254:115-118. CrossRef Medline

O'Leary T, Williams AH, Franci A, Marder E (2014) Cell types, network homeostasis, and pathological compensation from a biologically plausible ion channel expression model. Neuron 82:809-821. CrossRef Medline

Saito H, Okada M, Miki T, Wakamori M, Futatsugi A, Mori Y, Mikoshiba K, Suzuki N (2009) Knockdown of Cav2.1 calcium channels is sufficient to induce neurological disorders observed in natural occurring Cacnala mutants in mice. Biochem Biophys Res Commun 390:1029-1033. CrossRef Medline

Schulz DJ, Temporal S, Barry DM, Garcia ML (2008) Mechanisms of voltage-gated ion channel regulation: from gene expression to localization. Cell Mol Life Sci 65:2215-2231. CrossRef Medline

Song I, Kim D, Choi S, Sun M, Kim Y, Shin HS (2004) Role of the $\alpha 1 \mathrm{G}$ T-type calcium channel in spontaneous absence seizures in mutant mice. J Neurosci 24:5249-5257. CrossRef Medline

Tenney JR, Glauser TA (2013) The current state of absence epilepsy: can we have your attention? Epilepsy Curr 13:135-140. CrossRef Medline

Yang JW, Vacher H, Park KS, Clark E, Trimmer JS (2007) Trafficking-dependent phosphorylation of Kv1.2 regulates voltagegated potassium channel cell surface expression. Proc Natl Acad Sci U S A 104: 20055-20060. CrossRef Medline

Zamponi GW, Lory P, Perez-Reyes E (2010) Role of voltage-gated calcium channels in epilepsy. Pflugers Arch 460:395-403. CrossRef Medline

Zhang Y, Mori M, Burgess DL, Noebels JL (2002) Mutations in high-voltage-activated calcium channel genes stimulate low-voltage-activated currents in mouse thalamic relay neurons. J Neurosci 22:6362-6371. Medline 